\title{
SEASONAL VARIATION OF 2,4-D EXPORT THROUGH SURFACE RUNOFF FROM PASTURE
}

\author{
K. MÜLLER ${ }^{1}$, R. STENGER ${ }^{2}$ and A. RAHMAN ${ }^{1}$ \\ ${ }^{1}$ AgResearch, Ruakura Research Centre, Hamilton, New Zealand \\ ${ }^{2}$ Lincoln Environmental Research, P O Box 3062, Hamilton, New Zealand \\ Corresponding author: karin.mueller@agresearch.co.nz
}

\begin{abstract}
One day after the herbicide 2,4-D was applied to $1050 \mathrm{~m}^{2}$ of a pastoral hillslope in Waikato, runoff was generated with a sprinkler-type rainfall simulator and 2,4-D transport in surface runoff was measured. The runoff coefficients differed significantly between an autumn $(47 \%)$ and a spring (19\%) event in spite of similar pre-event soil water conditions. Saturation excess with a variable contributing area had earlier been identified as the main runoff generating process for the autumn event. In contrast, infiltration excess, possibly induced by treading effects and hydrophobicity are proposed as runoff causing processes for the spring event. The event-averaged 2,4-D concentration in runoff was higher in autumn $(0.49 \mathrm{mg} /$ litre $)$ than in spring $(0.24 \mathrm{mg} /$ litre $)$. Correspondingly the exported 2,4-D loss in autumn totalled $75 \mathrm{~g} / \mathrm{ha}$, which equals $7 \%$ of the applied mass, compared to only $14 \mathrm{~g} / \mathrm{ha}$ (or $1 \%$ ) during the spring event.
\end{abstract}

Keywords: saturation excess, variable source area concept, infiltration excess, lateral flow, field scale.

\section{INTRODUCTION}

Since their development 50 years ago, herbicides have been used extensively in agricultural production, but they have also had an adverse affect on environmental quality. Every herbicide application usually has some off-target effects on the environment. Non-point source pollution, including surface runoff, leaching, spray drift and drainage water, is responsible for residues in waterways. It is believed that in New Zealand, herbicide runoff from pasture contributes to surface water contamination (Wilcock \& Costley 1991). Field experiments in cropping situations overseas have produced evidence that major losses are always associated with heavy rainfall events that occur within the first 14 days of herbicide application (Wauchope 1978). This study concentrates on a worst case situation by using a rainfall simulator to produce a rainfall event strong enough to induce substantial surface runoff one day after herbicide application to pasture. The herbicide of choice was 2,4-D as it is a widely used herbicide on New Zealand pasture for controlling broadleaf weeds, belongs to the phenoxy hormones that constitute one of the most important pesticide classes in the country (Manktelow et al. 2005), and has been detected in New Zealand water resources (Close \& Rosen 2001). The objective of this study was to investigate the impact of seasonal plant and soil properties on 2,4-D concentration and loads in runoff from a pastoral hillslope section under conditions favourable for runoff generation.

\section{METHODS}

The project was conducted on a hillslope section of $1050 \mathrm{~m}^{2}$ in the Pukemanga catchment (Whatawhata Hill Country Research Station). The site was under a traditional sheep pasture with perennial ryegrass/white clover (Lolium perenne/Trifolium repens). The slopes of the hillslope section ranged from approximately $5^{\circ}$ to $35^{\circ}$. According to 
the New Zealand Soil Classification System (Hewitt 1998) the soil at the experimental site is classified as a Mottled Yellow Ultic Soil, which corresponds to an Aquic Hapludult (USDA classification system). Information on some physical properties determined at four soil profiles on the hillslope (Fig. 1) is compiled in Table 1. For a compilation of soil data see Müller et al. (2004). Soil texture is silt loam in the A-horizon and loamy clay or silty clay below. The topsoil horizons are well drained and underlain by an argillic $\mathrm{Bt}(\mathrm{g})$ horizon enriched with translocated clay. This horizon is strongly gleyed indicating prolonged periods of saturation and imperfect drainage conditions. The profiles showed some spatial variability (Table 1).

TABLE 1: Geometric means for vertical (and lateral) saturated hydraulic conductivity $\left(K_{s}, \mathrm{~mm} / \mathrm{h}\right)$ and bulk density $\left(\mathrm{kg} / \mathrm{m}^{3}\right)$ measured at four profiles. There were five replicates at the $0.1 \mathrm{~m}$ depth and three replicates at the other three depths.

\begin{tabular}{|c|c|c|c|c|}
\hline $\begin{array}{l}\text { Depth } \\
\text { (m) }\end{array}$ & $\begin{array}{c}\text { RW1 } \\
\text { Footslope }\end{array}$ & $\begin{array}{c}\text { RW4 } \\
\text { Backslope }\end{array}$ & $\begin{array}{c}\text { RW6 } \\
\text { Backslope }\end{array}$ & $\begin{array}{c}\text { RW7 } \\
\text { Shoulderslope }\end{array}$ \\
\hline \multicolumn{5}{|c|}{ Saturated hydraulic conductivity - vertical (and lateral) } \\
\hline 0.1 & $105(315)$ & $36(79)$ & $66(163)$ & $129(263)$ \\
\hline 0.35 & $1462(167)$ & $20(13)$ & $30(133)$ & $46(76)$ \\
\hline 0.5 & $90(14)$ & $2(18)$ & $13(30)$ & $20 \quad(2)$ \\
\hline 0.8 & $26 \quad(7)$ & $29(4)$ & $12(11)$ & (2) \\
\hline \multicolumn{5}{|c|}{ Bulk density } \\
\hline 0.1 & 912 & 1020 & 1010 & 1000 \\
\hline 0.35 & 1160 & 1320 & 1270 & 1160 \\
\hline 0.5 & 1260 & 1360 & 1110 & 1060 \\
\hline 0.8 & 1110 & 1270 & 1040 & 990 \\
\hline
\end{tabular}
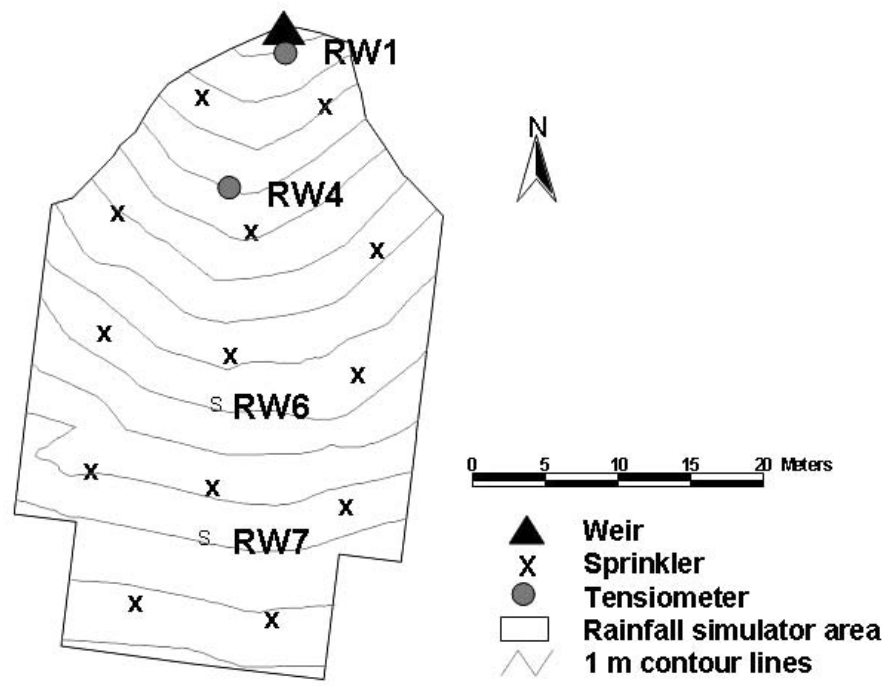

FIGURE 1: Instrumentation of the hillslope section. 
The hillslope was equipped with a range of instruments including a large sprinklertype rainfall simulator, as described in Elliott et al. (2002). In this study, rainfall events were simulated in autumn and in spring. During the autumn run, the locations RW1 and RW4 at the base of the hillslope were equipped with tensiometers (Fig. 1). Tensions were recorded every 15 min during the autumn event and every 5 min during the spring event at four soil depths, namely $0.1,0.25,0.5$ and $0.8 \mathrm{~m}$, except that the second depth was $0.35 \mathrm{~m}$ at RW4.

2,4-D ethylhexylester (Pasture Kleen ${ }^{\mathrm{TM}}$ ) was applied at $1050 \mathrm{~g} / \mathrm{ha}$ in 150 litres/ha using a knapsack sprayer on 11 June 2003 (autumn) and 21 October 2004 (spring). One day after the herbicide application, simulated rainfall was applied for approximately one hour at an average intensity of $40 \mathrm{~mm} / \mathrm{h}$. This event has an 8-year annual recurrence interval.

Runoff was logged in a $0.305 \mathrm{~m}$ H flume installed at the outlet of the hillslope section. Runoff samples of 1 litre were taken every 3 min during the rainfall events and at 15 -min intervals thereafter for $120 \mathrm{~min}$. Dissolved 2,4-D concentrations in the runoff water were analysed after acidification, clean-up via SPE and subsequent esterification by HPLC. The procedure is described in detail elsewhere (Müller et al. 2006).

\section{RESULTS AND DISCUSSION}

\section{Soil hydrological response to the rainfall events}

The initial soil hydrological conditions for the two rainfall simulations in this study were similar as both events were simulated during periods of wet weather characterised by frequent rain and relatively low evaporation rates. Water tensions recorded at the locations RW1 and RW4 ranged between -150 and $-400 \mathrm{~mm}$ for the autumn event and between -190 and $-540 \mathrm{~mm}$ for the spring event (Fig. 2).

A detailed analysis of the hydrological response of the hillslope section to the autumn event is presented in Müller et al. (2006). In summary, the footslope (RW1) was very quickly and completely saturated from the bottom of the profile to the top. The saturated conditions persisted for many hours after the rainfall event. Lateral subsurface flow down the hillslope was identified as the key process for the hydrological response observed and

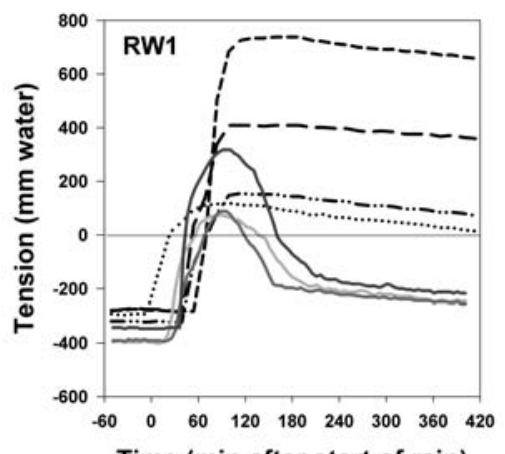

Time (min after start of rain)

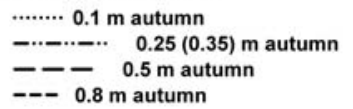

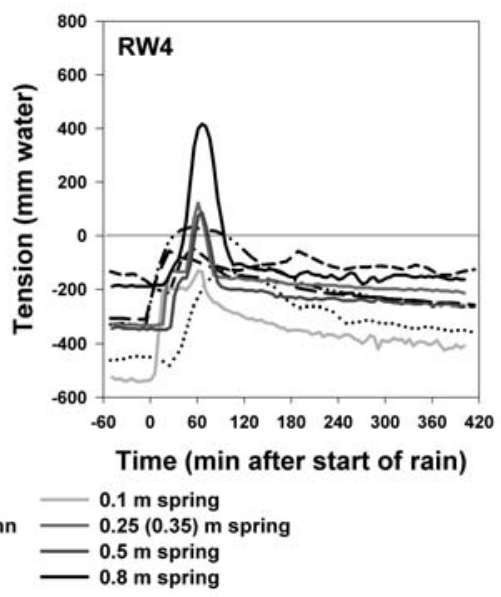

FIGURE 2: Soil water tension measured at four depths at RW1 $(0.1,0.25,0.5$ and $0.8 \mathrm{~m})$ and $\mathrm{RW} 4(0.1,0.35,0.5$ and $0.8 \mathrm{~m})$ during the spring and the autumn events. (Readings at the $0.8 \mathrm{~m}$ depth for RW1 in the spring event are missing.) 
this hypothesis was based on the timing and length of saturation, as well as on additional laboratory data on lateral and vertical saturated hydraulic conductivities (Table 1).

A totally different response was seen to the simulated rainfall in spring, even though the initial hydrological conditions for both runs were almost identical. The soil water tensions recorded at RW1 and RW4 for both events are shown in Figure 2. The most significant difference between the tensions recorded at RW1 during the two events was not the recorded absolute values, but the time it took to reach saturation and the length of time saturation prevailed. While the subsoil depths at RW1 reached saturation at comparable times during both events, a major difference was observed at the $0.1 \mathrm{~m}$ depth. In autumn, saturation of the topsoil was reached after about $15 \mathrm{~min}$ of rain, coinciding with the first surface runoff being measured at the weir. In contrast, saturation of the topsoil was only recorded after almost $60 \mathrm{~min}$ of rain in spring, i.e. at the end of the event and approximately $40 \mathrm{~min}$ after the onset of surface runoff at the weir. While saturated conditions at all depths of RW1 lasted for more than 8 hours in autumn, they lasted only for a maximum of 2.5 hours in spring.

During the autumn event, only the $0.35 \mathrm{~m}$ depth tension data from RW4 clearly indicated saturated conditions, while all other depths remained just below full saturation. In contrast, full saturation was recorded in spring at all depths but $0.1 \mathrm{~m}$, reflecting the build-up of a perched water body.

It had earlier been concluded that the quickly developing and long-lasting saturation observed in autumn at RW1 could be explained by the steady replacement of vertically draining water by lateral flow arriving from upslope locations, which also prevented the build-up of perched water at the upslope profile RW4 (Müller et al. 2006). Conversely, observing a build-up of perched water at RW4 in spring while not observing an extended period of saturated conditions at RW1 would indicate that downslope lateral flow was insignificant during the spring event.

\section{Surface runoff}

In line with the soil water tension, the surface runoff response also varied markedly between the autumn and spring events (Fig. 3). In autumn, runoff started after 16 min and peaked at the end of the rainfall $(66 \mathrm{~min})$ with a flow rate of 6.9 litres/s. Surface runoff started only slightly later in spring $(20 \mathrm{~min})$, but the peak flow rate, reached at the end of the rainfall (59 min), was only 3.5 litres/s. Accordingly, the runoff coefficient was $47 \%$ in autumn, but $19 \%$ in spring.

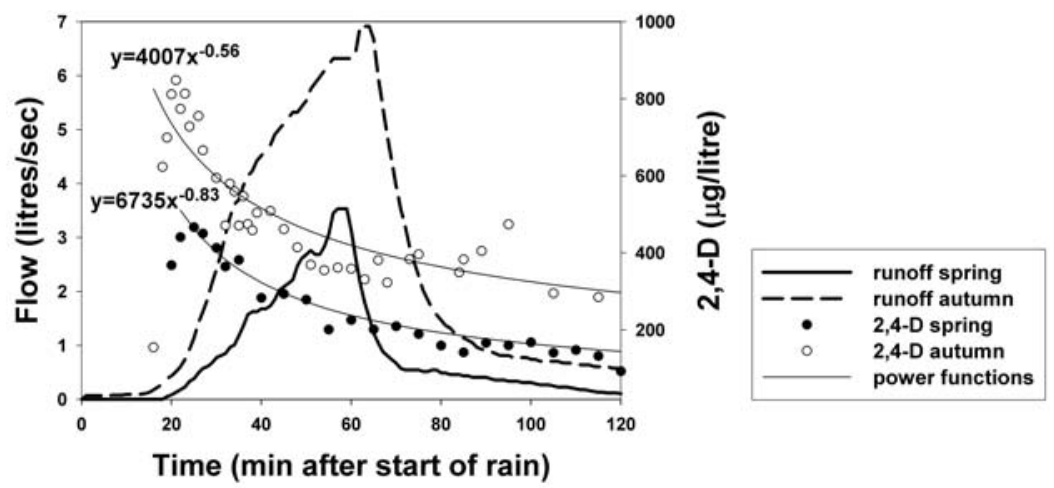

FIGURE 3: Flow rate (litres/s) of runoff, 2,4-D concentrations and power functions fitted to concentration data for the first $\mathbf{1 2 0} \mathrm{min}$ after the start of simulated rainfall during the autumn and the spring events. 
The conclusion from the analysis of the hydrological response for the autumn event was that runoff was mainly generated as saturation excess with a variable contributing area in the convergent area of the hillslope section (Müller et al. 2006). In spring, saturation excess could not have been the dominating runoff generating process as saturated topsoil conditions only occurred 40, 20 and 35 min after runoff had started at RW1, RW6 and RW7, respectively, and not at all at RW4. The saturated hydraulic conductivities measured in the laboratory (Table 1) would suggest that infiltration excess is not likely to have been the main runoff generating process, as they were higher than the average rainfall intensity. However, saturated hydraulic conductivities at the time of the spring event might have been lower than in winter 2003 when the soil samples for the lab analyses were taken. Seasonal variability in hydraulic conductivities of the soil in the Pukemanga catchment has already been reported by Elliott et al. (2002). Grazing of the hillslope by sheep during the week prior to the spring event may have reduced topsoil infiltration rates. Moreover, water repellent plant and/or topsoil conditions might have contributed to the initiation of runoff. Hydrophobicity is transient and can significantly alter the hydrological properties of soils and lead to a reduction in infiltration capacity and enhance overland flow (Shakesby et al. 2000). The production of hydrophobic compounds by plants has been suggested as a mechanism for suppressing the germination of competing vegetation in spring (Doerr et al. 2000). However, hydrophobicity would generally be expected to play a major role only in summer under drier pre-event soil conditions.

\section{Dissolved herbicide loss in surface runoff}

As the pasture cover was very good before both events, it can be assumed that at least $40 \%$ of the herbicide applied was intercepted by the pasture foliage (Linders et al. 2000) and was no longer available for runoff transport processes during the rainfall events $24 \mathrm{~h}$ after herbicide application. During the entire runoff event the 2,4-D concentrations in autumn were above those measured in spring (Fig. 3). Consequently the event-averaged 2,4-D concentration in runoff during the autumn event $(0.49 \mathrm{mg} /$ litre $)$ was markedly higher than in spring $(0.24 \mathrm{mg} / \mathrm{litre})$. The opposite was expected, namely higher $2,4-\mathrm{D}$ concentrations in spring than in autumn, due to the lower runoff volume and thus lower dilution factor in spring compared to autumn. It is likely that higher volatilisation losses in spring due to higher average ambient temperature $\left(19^{\circ} \mathrm{C}\right.$ versus $\left.14^{\circ} \mathrm{C}\right)$ contributed to the difference in herbicide concentration levels.

In both events the herbicide concentrations showed an exponential decrease with time (Fig. 3), which was best described by power functions with regression coefficients of 0.82 and 0.95 in autumn and spring, respectively. The observed concentration pattern can be explained by progressive desorption of 2,4-D from soil particles into the runoff mixing zone (Ma et al. 2004). The desorbed herbicide was then either transported into the soil with infiltrating water or transported downslope in surface runoff. The fate of the herbicide leached into the soil profile differed during the two events. In spring the infiltrating water built up in the soil, while in autumn a substantial part of the infiltrating water flowed as subsurface lateral downslope and exfiltrated in the footslope where it mixed with surface runoff water. The lower regression coefficient in autumn is due to the distinct jump in concentration values coinciding with the end of the rainfall event. At this stage the contribution of exfiltrating subsurface flow to surface runoff gained in relative importance, as direct runoff of rain falling onto saturated soil ceases. The exfiltrating water quite likely contained higher herbicide concentrations than the water running off soil surfaces depleted of herbicide after an hour of heavy rainfall. The exported 2,4-D loss in autumn totalled $75 \mathrm{~g} / \mathrm{ha}$, which equals $7 \%$ of the applied mass compared to only $1.4 \%$ (14 g/ha) during the spring event.

\section{ACKNOWLEDGEMENTS}

We would like to thank NIWA and Landcare Research Ltd. for letting us use their equipment. We also thank Jan Mertens, Eva Klingelmann, Trevor James, Mike Trolove and Markus Haas. Funding for the work was provided by the New Zealand Foundation for Research, Science and Technology (AGRX0105, LVLX0302). 


\section{REFERENCES}

Close ME, Rosen MR 2001. 1998/99 national survey of pesticides in groundwater using GCMS and ELISA. New Zealand Journal of Marine \& Freshwater Research 35:205-219.

Doerr SH, Shakesby RA, Walsh RPD 2000. Soil water repellency: its causes, characteristics and hydro-geomorphological significance. Earth-Science Reviews 51:33-65.

Elliott AH, Tian YQ, Rutherford JC, Carlson WT 2002. Effect of cattle treading on interrill erosion from hill pasture: modelling concepts and analysis of rainfall simulator data. Australian Journal of Soil Research 40:963-976.

Hewitt AE 1998. New Zealand Soil Classification. Manaaki Whenua Press, Lincoln, New Zealand. 133 pp.

Linders J, Mensink H, Stephenson G, Wauchope D, Racke K 2000. Foliar interception and retention values after pesticide application. A proposal for standardized values for environmental risk assessment. Pure and Applied Chemistry 72(11):2199-2218.

Ma QL, Rahman A, Holland PT, James TK, McNaughton DE 2004. Field dissipation of acetochlor in two New Zealand soils at two application rates. Journal of Environmental Quality 33:930-938.

Manktelow D, Stevens P, Walker J, Gurnsey S, Park N, Zabkiewicz J, Teulon D, Rahman A 2005. Trends in pesticide use in New Zealand: 2004. HortResearch Client Report No. 17962, Report to the Ministry for the Environment, Wellington, New Zealand. 78 pp.

Müller K, Adams R, Stenger R 2004. Soils in the Pukemanga catchment with emphasis on hydraulic properties. Client Report AgResearch Ltd., Hamilton, New Zealand. $32 \mathrm{pp}$.

Müller K, Stenger R, Rahman A 2006. Herbicide loss in surface runoff from a pastoral hillslope in the Pukemanga catchment (New Zealand): The role of pre-event soil water content. Agriculture Ecosystem and Environment 112(4):381-390.

Shakesby RA, Doerr SH, Walsh RPD 2000. The erosional impact of soil hydrophobicity: current problems and future research directions. Journal of Hydrology 231-232: 178-191.

Wauchope RD 1978. The pesticide content of surface water draining from agricultural fields - a review. Journal of Environmental Quality 7:459-472.

Wilcock RJ, Costley KJ 1991. Stream run-off losses and soil and grass residues of triclopyr applied to hillside gorse. New Zealand Journal of Agricultural Research 34:354-357. 